\title{
Daimi Diş Germi Eksikliği Gözlenen Süt Dişlerinin Gutaperka/ Kök Kanal Dolum Patı ile Tamamlanmış Kök Kanal Tedavilerinin Retrospektif Olarak İncelenmesi
}

\author{
Retrospective Investigation of Root Canal Treatments Completed with \\ Gutta-Percha/Root Canal Filling Material in Primary Teeth without Successors
}

\author{
Merve ABAKLI INCI ${ }^{* 1}$ (D) \\ merveabakli@gmail.com
}

\author{
Hazal ÖZER ${ }^{1}$ (D) \\ hazal07130zer@gmail.com
}

Fatma ÜZÜMCÜ UYUMAZ ${ }^{1}$ (D)
fatma.uzumcu93@gmail.com
Zeynep YALÇINKAYA ${ }^{1}$ (D)

zyalcinkay@gmail.com

\begin{abstract}
öZ
Amaç: Çalışmada, önceki yıllarda pedodonti kliniğinde uygulanan daimi diş germi eksikliği mevcut olup gutaperka ve kök kanal dolum patı ile tedavisi tamamlanan dişler tespit edilmiştir. Vakaların günümüze kadar mevcut olan kontrol radyografileri ve sistemde kayıtlı klinik bilgileri incelenerek uzun dönem bașarısının araștırılması amaçlanmıștır.

Gereç ve Yöntemler: Program üzerinden yapılan araştırma sonucu 2015-2021 yılları arasında 84 hastanın 105 süt azı dişine daimi kanal tedavisi yapıldığı belirlenmiștir. Bu tedavilerden sistemde kayıtlı klinik bilgi ve radyografisi olan süt azı dişleri değerlendirmeye alınmıștır. Bu hastaların klinik ve radyolojik muayenesi sırasında ağrı, anormal mobilite, perküsyonda hassasiyet, şişlik, apse, fistül, internal ve eksternal patolojik rezorbsiyon, periapikal ve interradiküler radyolüsensi gözlenmeyen hastalarda kanal tedavileri başarılı kabul edilmiştir. Sonuçların istatistiksel olarak değerlendirilmesinde tanımlayıcı analizler kullanılmıștır.

Bulgular: Tarama sonucunda 20 (\%23.8) kişiye ait 22 (\%20.9) süt azı dişine çekim yapıldığı kaydedilmiş ve başarısız tedaviler içerisinde değerlendirilmiştir. Sistemde kayıtlı verisi bulunan 47 süt azı dişinin kök kanal tedavisi klinik ve radyografik olarak değerlendirilmiştir. Buna göre 6. ayda \%60, 1. yılda \%26.6, 2. yılda \%25 ve 3. yılda \%30 başarı oranı görülmüştür.

Sonuç: Çalışma sonucu görülen yüksek başarısızlık oranı sebebiyle alternatif kök kanal dolum materyalleri ve teknikleri değerlendirilmelidir. Alternatif teknikler ile birlikte daha uzun takip süreli prospektif çalışmaların planlanması önerilmektedir.
\end{abstract}

Anahtar Kelimeler: Gutaperka, Hipodonti, Pulpektomi, Süt dişi

$\begin{array}{lll}\text { Geliș: } 15.03 .2021 & \text { Kabul: 21.04.2021 } & \text { Yayın: } 30.04 .2021\end{array}$

\begin{abstract}
Aim: In the study, there was permanent tooth germ deficiency applied in pedodontics clinic in previous years, and teeth that were treated with guttapercha and root canal filling material were determined. It was aimed to investigate the long-term success of the cases by examining control radiographs and clinical information recorded in system.

Material and Methods: As a result of the research conducted through program, it was determined that 105 primary molars of 84 patients were performed permanent root canal treatment between 2015 and 2021. Among these treatments, deciduous teeth with clinical information and radiography recorded in system were evaluated. Root canal treatment of the patients was judged to be successful in patients who didn't have pain, abnormal mobility, sensitivity in percussion, swelling, abscess, fistula, internal and external pathological resorption, periapical and interradicular radiolucency during clinical and radiological examination. Descriptive analyzes were used for statistical evaluation of results.

Results: As a result of the screening, it was recorded that 22 (20.9\%) deciduous teeth belonging to 20 (23.8\%) people were extracted and were considered as unsuccessful treatments. Root canal treatment of 47 primary molar with recorded data in system was evaluated clinically and radiographically. Accordingly, the success rate was $60 \%$ in 6 th month, $26.6 \%$ in 1 st year, $25 \%$ in 2 nd year and $30 \%$ in 3rd year.

Conclusion: Due to high failure rate seen as a result of study, alternative root canal filling materials and techniques should be evaluated. It is recommended to plan prospective studies with longer follow-up periods with alternative techniques.
\end{abstract}

Keywords: Gutta-percha, Hypodontia, Primary tooth, Pulpectomy
Received: 15.03 .2021
Accepted: 21.04 .2021
Published: 30.04 .2021

Atıf / Citation: Abaklı İnci M, Özer H, Üzümcü Uyumaz F, Yalçınkaya Z. Daimi diş germi eksikliği gözlenen süt dişlerinin gutaperka/ kök kanal dolum patı ile tamamlanmış kök kanal tedavilerinin retrospektif olarak incelenmesi. NEU Dent J. 2021;1:19-25.
* Sorumlu Yazar / Corresponding Author
1. Necmettin Erbakan Üniversitesi Diş Hekimliği Fakültesi Pedodonti AD Konya, Türkiye
"This article is licensed under a $\underline{\text { Creative }}$ Commons Attribution-NonCommercial 4.0 International License (CC BY-NC 4.0) 


\section{GíRiş}

Çocukların orofasiyal gelişimi için, süt dişlerinin mümkün olduğu kadar korunması büyük önem taşımaktadır. Süt dişleri başlıca ark uzunluğunu ve çiğneme fonksiyonunu koruduğu için, klinisyenler süt dişi patolojilerine aşina olmalıdır. ${ }^{1}$

Süt dişi patolojilerinin tanısı klinik ve radyografik olarak yapılır. Derin çürük bulunan süt dişlerindeki tedavi seçenekleri şunlardır: pulpatomi, pulpektomi, çekim. ${ }^{2}$ Dental radyografide kemik rezorbsiyonu gözlenmeyen veya radiküler pulpa dokusunda enfeksiyon belirtileri olmayan vakalardwa vital amputasyon prosedürü tercih edilir. ${ }^{3}$ Derin çürük ile ekspoze olan süt dişlerinde koronal pulpanın amputasyonu sonrası hiperemi mevcut ise veya radiküler pulpa nekrotik ise pulpektomi endikedir. Fakat diş yapısında restore edilemeyecek kadar kayı, internal ve eksternal kök rezorbsiyonu, pulpa odasında perforasyon, aşırı diş mobilitesi, daimi diş folikülünü içeren periapikal enfeksiyon durumlarında pulpektomi kontrendikedir, dişin çekimi düşünülür. ${ }^{4}$

Süt dișlerinde kök kanal tedavisinin amacı daimi diș doğal bir şekilde sürene kadar, süt dişini semptomsuz bir şekilde ağızda tutmaktır. Pulpektomi sonrası yeterli restorasyon yapımı ile ark uzunluğu korunur, çiğneme ve estetik fonksiyon sürdürülür, zararlı dil alışkanlıkları önlenir ve konuşmada değişikliklerin önüne geçilir. ${ }^{5}$ Süt dişlerinde kök kanal tedavisi; daimi dişlere benzer şekilde, bütün bakteriler, nekrotik ve vital pulpa kalıntıları ile enfekte dentinin çıkarılması sonrasında kök kanallarının hermetik bir şekilde doldurulmasını amaçlar.6 İdeal süt dişi kök kanal dolum materyali bazı kriterleri içermelidir: süt dişi kökü ile aynı oranda rezorbe olmalı, periapikal dokulara ve daimi diş germine zararsız olmalı, apeksten taştı̆̆ında rezorbe olabilmeli, antiseptik olmalı, kanala kolayca doldurulabilmeli veya kolayca uzaklaştırılabilmeli, nontoksik olmalıdır.2

Süt dişi kanal tedavisi dolum materyali olarak rapor edilmiş en çok kullanılanlar çinko oksitöjenol (ZOE), iodoform ve kalsiyum hidroksit patıdır. ${ }^{2} \mathrm{ZOE}$, hiperemik süt dişi pulpasında, iodoform içeren kalsiyum hidroksit patına göre daha başarılıdır. Fakat apeksten taştığında sert bir kitle oluşturduğu için daimi diş sürme yolunu değiştirebilir ve fizyolojik kök rezorbsiyonuna oranla daha yavaș rezorbe olur. İodoform patının \%65-\%100 arasında başarı oranı rapor edilmiştir. Dezavantajı ise; kanal tedavisi yapılmayan dişlere göre kök rezorbsiyonunu hızlandırabilmesidir. Kalsiyum hidroksit patının başarı oranı \%86.7- \%100 arasındadır. Başlıca dezavantajı ise hiperemik pulpası olan dişlerde kullanıldığında vital pulpa kalıntıları ile teması sonrası inflamatuar kök rezorbsiyonunu başlatabilmesidir. Başlıca iodoform ve kalsiyum hidroksit içeren vitapeks patı, süt dişi kökünden erken rezorbe olabilmektedir. Hastalık belirtisi göstermeden ekstraradiküler ve intraradiküler olarak rezorbe olmasının süt dişi prognozuna etkisi ileri çalışmalarla desteklenmelidir. ${ }^{5}$

Hipodonti, en sık karşılaşılan gelişimsel diş anomalisidir.,8 Yapılan birçok çalışmada üçüncü molar dişlerden sonra en çok eksikliği görülen diş daimi ikinci premolar diş olduğu belirtilmiştir. ${ }^{7} \mathrm{Bu}$ vakalarda pedodontist ve ortodontist tedavi sürecini birlikte şekillendirir. ${ }^{8}$ Çapraşıklık mevcut olan hastalarda süt dişinin çekimi yapılarak boşluğun spontan kapanması beklenirken ortodontik problemi olmayan hastalarda ise orofasiyal gelişim tamamlanana kadar süt dişini mümkün olan en uzun süre yerinde tutmak amaçlanır. ${ }^{9}$ İnce mine ve dentin kalınlıklarına ve yüksek pulpa boynuzlarına sahip olan bu dişler, amaca uygun şekilde uzun süre ağızda yer aldıklarından sıklıkla mikrobiyal pulpal tutuluma maruz kalırlar. ${ }^{7}$

Daimi diş germi olmayan süt dişlerinin kök kanal tedavisi ise daha önce bahsedilen materyaller yerine rezorbe olmayan gutaperka ve kök kanal dolum patı ile yapılır. ${ }^{10}$ Bunun yanında MTA ve Biodentin de kanal dolum materyali olarak kullanılabilir. ${ }^{11}$ Daimi dişin kök kanal tedavisi yapılırken uygulanan prosedürler geçerlidir. Fakat kök kanal anatomisi daimi dişlere göre düzensizlikler gösterdiği için tedavi sırasında zorluklarla karşılaşılmaktadır. ${ }^{8}$ Rezorbe olmayan bir kök kanal dolgusu kullanmak, süt dişini kök rezorbsiyonu olmadan mümkün olan en uzun süre ağızda tutmayı amaçlar. $\mathrm{Bu}$ sayede genç veya 20'li yaşlara kadar implant yapılması planlanan bölgede gerekli kemik dokusu korunmuş olur. ${ }^{7}$

$\mathrm{Bu}$ çalışmada, önceki ylllarda pedodonti kliniğinde uygulanan daimi diş germi eksikliği mevcut olup gutaperka ve kök kanal dolum patı ile tedavisi tamamlanan dişler tespit edilmiştir. Vakaların günümüze kadar mevcut olan kontrol radyografileri ve sistemde kayıtlı klinik bilgileri incelenerek uzun dönem başarısının araştırılması amaçlanmıştır.

\section{GEREC VE YÖNTEMLER}

Çalışmamız Necmettin Erbakan Üniversitesi Diş Hekimliği Fakültesi İlaç ve Tıbbi Cihaz Dışı Araștırmalar Etik Kurulu'nun 11.06.2020 tarihinde yapılan 2020/05 sayılı etik kurul onayı ile yürütülmüștür. 2015-2021 yılları arasında Necmettin Erbakan Üniversitesi Diş Hekimliği Fakültesi Pedodonti kliniğine başvuran 9-16 yaş arası tüm hastalar program üzerinden geriye yönelik olarak taranmıştır. Tarama, panoromik ve periapikal radyografiler üzerinden konjenital daimi diş eksikliği olduğu için gutaperka/kök kanal dolum patı ile kök kanal tedavisi yapılmış süt azı dişine sahip hastaları belirlemek üzere sınırlandırılmıștır. Sonuç olarak bu yıllar 
arasında 84 hastada 105 süt azı dișine daimi kök kanal tedavisi yapıldı̆̆ kök kanal tedavileri günümüze kadar mevcut olan takip radyografileri ve sistemde kayıtlı klinik bilgileri aracılığı ile incelenmiştir.

\section{Kanal Tedavisi Prosedürü}

Tüm tedaviler pedodonti kliniğinde çalıșan hekimler tarafından aynı prosedür izlenerek yapılmıștır. Kliniğe başvuran hastalardan alınan teşhis radyografisinde konjenital daimi diş eksikliği tespit edildiğinde veliye gerekli açıklama yapılarak tedavi süreci șekillenmiștir. Kök kanal tedavisi endikasyonu olan alt çene süt azı dișlerinde inferior alveolar anestezi ile üst çene süt azı dişlerinde infiltratif anestezi ile sinir blokajı (Maxicain Fort 80 $\mathrm{mg} / 2 \mathrm{ml}+0.02 \mathrm{mg} / 2 \mathrm{ml}$ ) sağlanmıştır. İzolasyon rubberdam ya da ruberdam uygulanamayan çocuk hastalarda pamuk rulolar ile sağlanmıştır. Bütün çürük dokusu temizlendikten sonra giriş kavitesi hazırlanmıștır. 15 numara steril $\mathrm{K}$ file (Mani, Inc, Tochigi, Japan) ile periapikal radyografi aracılığıyla radyolojik apeksten $2 \mathrm{~mm}$ kısa olacak șekilde boy tespiti yapılmıștır. Süt dişlerinin kanal duvarları ince olduğu için şekillendirme sırasında perfore etmemek amaciyla 30 numara K file'a (Mani, Inc, Tochigi, Japan) kadar genişletme yapılmıştır. Şekillendirme step-back tekniği kullanılarak gerçekleştirilmiştir. Kanallar enstrümentasyon aralarında $2 \mathrm{ml} \% 2.5$ konsantrasyonunda sodyum hipoklorit ile irrige edilmiştir. Final irrigasyonu $5 \mathrm{ml}$ steril serum fizyolojik ile yapılmıştır. Kanallar apeksten $2 \mathrm{~mm}$ kısa olacak şekilde paper pointler yardımıyla kurulanmıştır. 30 numara master kon yerleștirildikten sonra 15, 20, 25 numara lateral konlar (Dentplus, Korea) ile desteklenerek lateral kondensasyon tekniği ile kanal dolumu yapılmıștır. Kanal patı olarak Sealapeks (Kerr Co., Michigan) kullanılmıştır. Kanal üzeri cam iyonomer siman (Nova glass, Imicryl, Konya, Türkiye) ile kapatılarak kompomer dolgu materyali (Nova kompomer, Imicryl, Konya, Türkiye) kullanılarak restore edilmiştir

\section{Klinik ve Radyolojik Değerlendirme}

Klinik değerlendirme için hastalar kontrole geldiklerinde sisteme kaydedilen verileri değerlendirilmiştir. Radyolojik değerlendirme için ise sistemde mevcut olan periapikal ya da panoromik radyografiler incelenmiştir. Radyografilerde fizyolojik ve patolojik kök rezorpsiyonu ile periapikal- interradiküler lezyon oluşumu değerlendirilmiştir.

Klinik ve radyografik olarak;

- Ağrı

- Anormal mobilite

- Perküsyonda hassasiyet

- Şişlik
- İnternal ve eksternal patolojik kök rezorbsiyonu

- Periapikal ve interradiküler radyolüsensi

- Apse ve fistül formasyon

- İnfraokluzyon

gözlenmeyen hastalarda kanal tedavisi bașarılı kabul edilmiştir. ${ }^{2}$

\section{İstatistiksel Analiz}

Değerlendirmeler 2 hekim tarafından yapılarak ortak karar alınmıştır. Sonuçların değerlendirilmesi için tanımlayıcı analizler yapılmıştır.

\section{BULGULAR}

Yapılan tarama sonucunda 2015-2021 yılları arasında daimi diş eksikliği görüldügü için gutaperka-kök kanal dolum patı ile kök kanal tedavisi yapılan, 84 hastaya ait 105 süt azı diși belirlenmiștir. Yine tarama sonuçlarından biri olarak bu hastalardan 20 (\%23.8) kişiye ait 22 (\%20.9) süt azı dişine çekim yapıldığı kaydedilmiş ve başarısız tedaviler içerisinde değerlendirilmiştir.

Belirlenen listedeki hastaların sistemde kayitlı olan radyografik kayıtları ile klinik bilgileri tek tek incelenmiştir. Buna göre 34 (\%40.4) hastaya ait 47 (\%44.7) süt azı dişinin kontrol radyografisinin ve klinik bilgisinin mevcut olduğu tespit edilip değerlendirmeye alınmıştır. Değerlendirme yapılırken 6 aylık, 1 yıllık, 2 ylllı ve 3 ylllık kontrol radyografileri şeklinde gruplanmıştır. 6 aylık takip röntgeni olan hastalar değerlendirildiğinde başarı oranı \%60, 1 ylllı takip röntgeni olan hastalar değerlendirildiğinde başarı oranı \%26.6, 2 yıllık takip röntgeni olan hastalar değerlendirildiğinde başarı oranı $\% 25$ ve 3 ylllık takip röntgeni olan hastalar değerlendirildiğinde ise başarı oranı \%30 olarak belirlenmiştir. Başarılı ve başarız tedaviler sayısal olarak Tablo 1'de gösterilmiștir. Değerlendirilen hastalara ait bașarılı (Resim 1) ve bașarısız tedaviler (Resim 2, Resim 3, Resim 4, Resim 5, Resim 6) için örnek radyografiler gösterilmiştir.

Tablo 1: Zamanlara göre başarılı ve başarısız tedavilerin sayısal değerleri

\begin{tabular}{|c|c|c|c|c|}
\hline & $\mathbf{6 ~ A Y}$ & $\mathbf{1}$ YIL & 2 YIL & 3 YIL \\
\hline BAŞARILI & $6(60)$ & $\mathbf{n}(\%)$ & $\mathbf{n}(\%)$ & $\mathbf{n}(\%)$ \\
\hline BAŞARISIZ & $4(40)$ & $11(36.3)$ & $24(75)$ & $7(70)$ \\
\hline
\end{tabular}


Resim 1: 2 yıllık kontrol. a. Başlangıç radyografisi. b. Başarılı bir kök kanal tedavisi
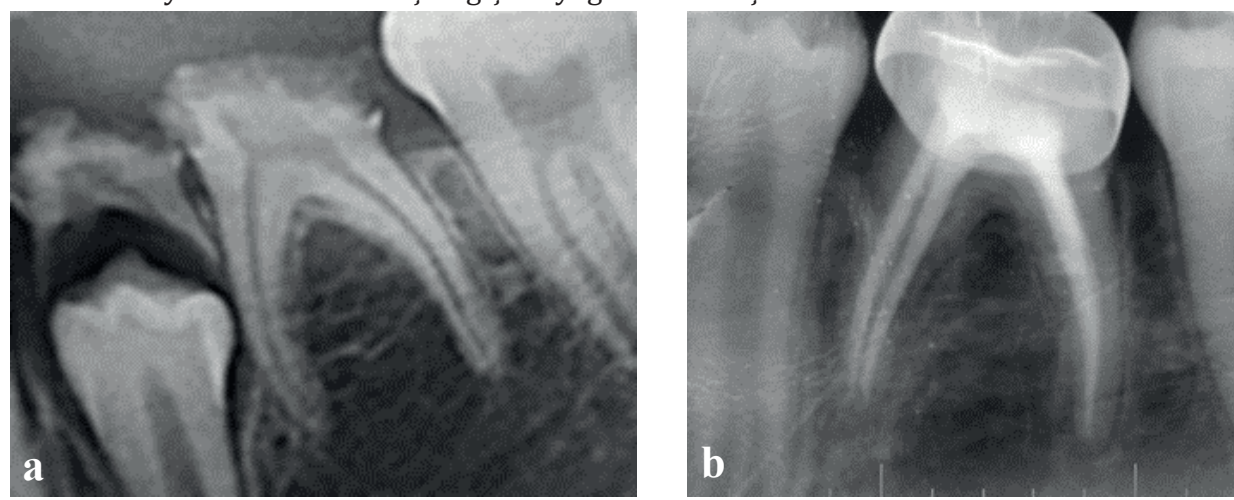

Resim 2: 2 yıllık kontrol. a. Başlangıç radyografisi. b. Patolojik kök rezorbsiyonu sebebiyle başarısız bir kök kanal tedavisi
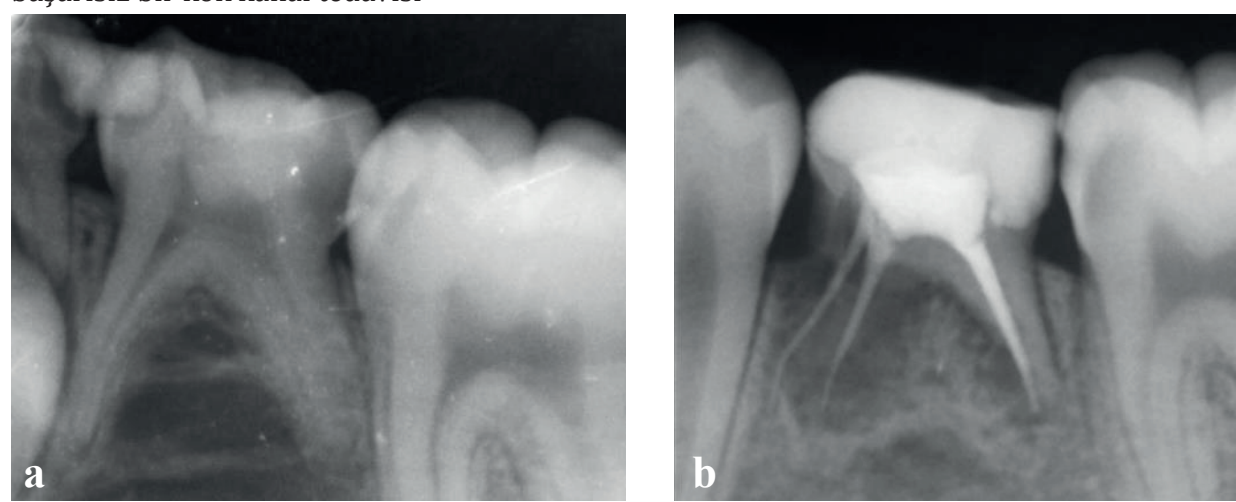

Resim 3: 2 yıllık kontrol. a. Başlangıç radyografisi. b. Yaygın lezyon ve kök rezorbsiyonu sonucu olușan anormal mobiliteye bağlı bașarısız bir tedavi
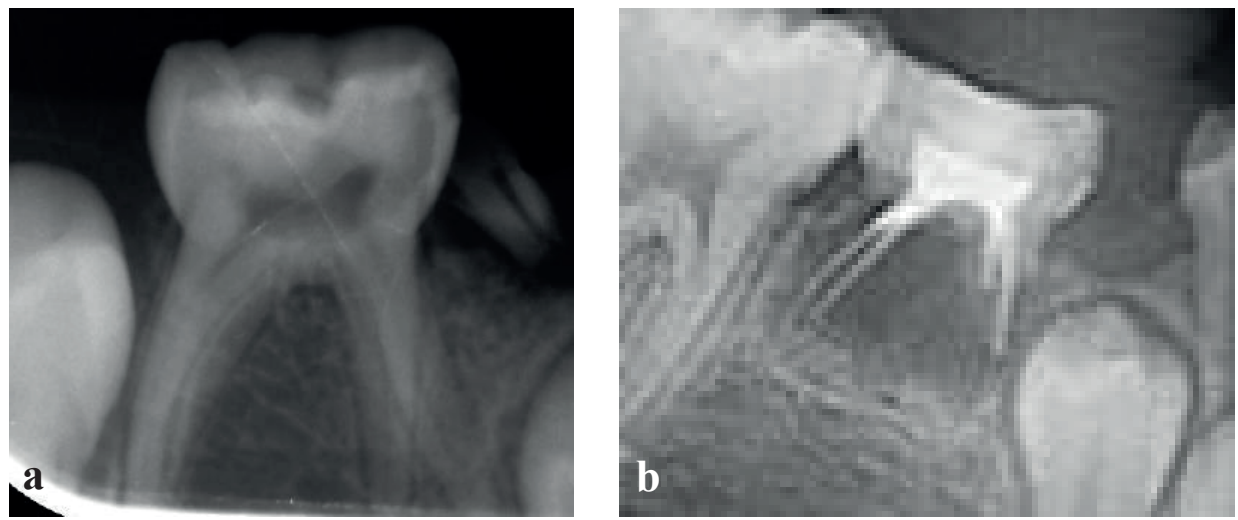

Resim 4: 3 yıllık kontrol. a. Başlangıç radyografisi. b. Furkasyonda kemik kaybı ve dişin infraokluzyonda kalması sonucu bașarısız bir tedavi
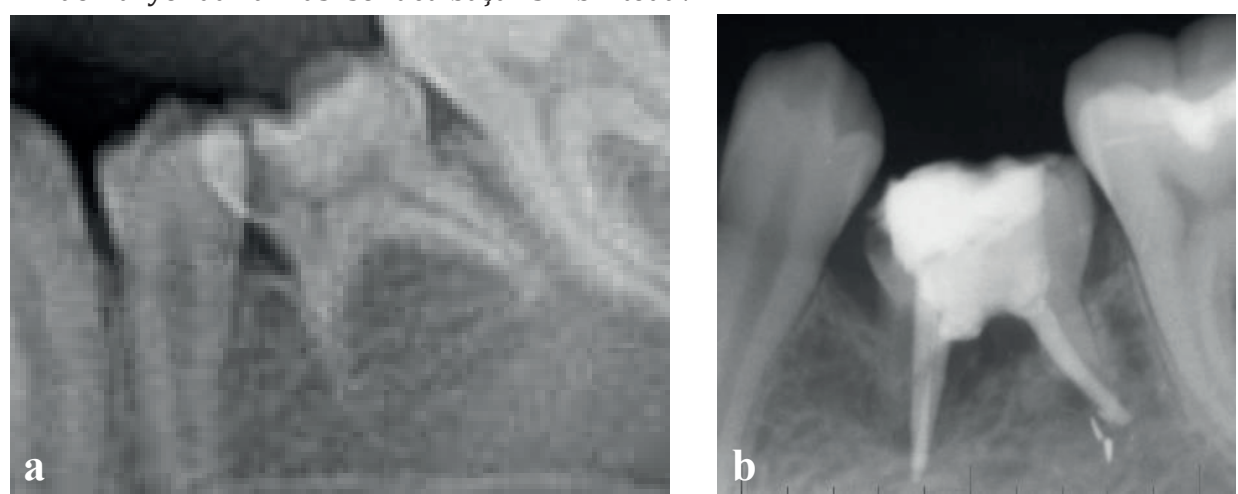
Resim 5: 2 yıllık kontrol. b. Başlangıç radyografisi. b. İnternal kök rezorbsiyonuna bağlı başarısız bir tedavi
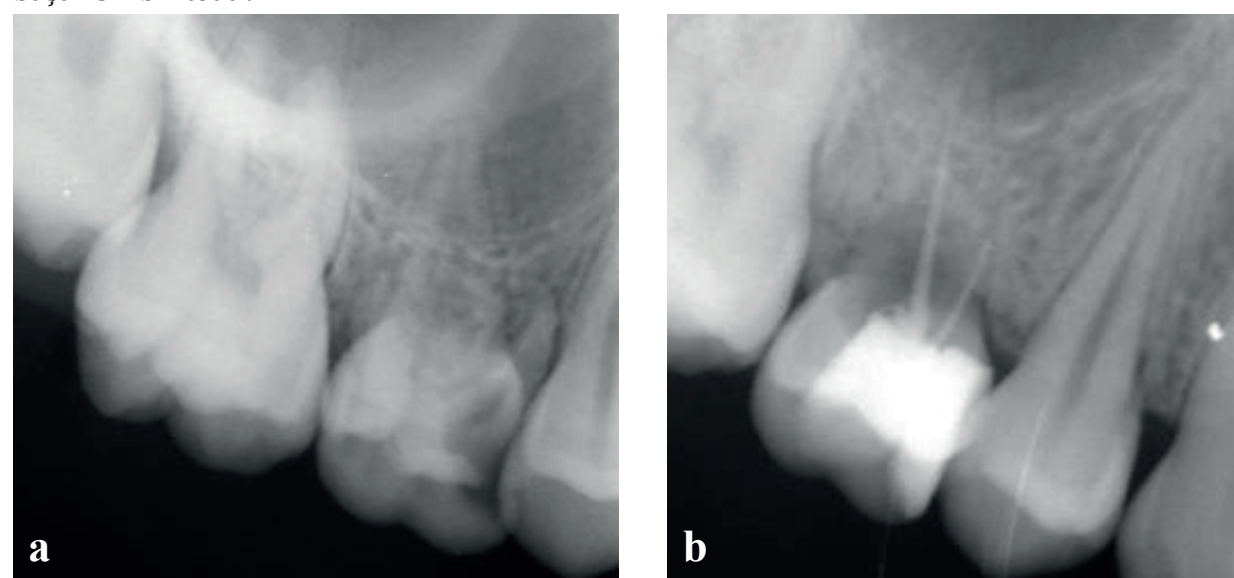

Resim 6: 2 yıllık kontrol. a. Başlangıç radyografisi. b. Apikal ve interradiküler lezyon oluşumuna bağlı bașarısız bir tedavi
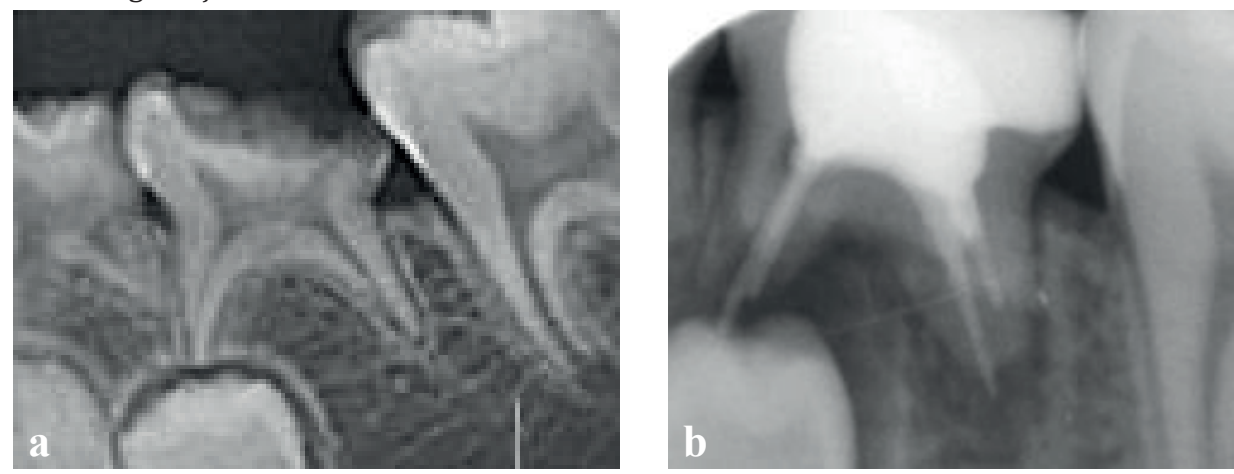

Değerlendirilme sırasında, $1(\% 2.17)$ tedavi internal rezorbsiyon sebebi ile, 1 (\%2.17) tedavi infraokluzyon ve interradiküler lezyon sebebi ile, 4 tedavi (\%8.69) sadece periapikal lezyon sebebi ile, $6(\% 13.04)$ tedavi periapikal ve interradiküler lezyon sebebi ile, 3 (\%6.52) tedavi periapikal lezyona eșlik eden patolojik kök rezorbsiyonu sebebi ile başarısız kabul edilmiştir. 26 (\%56.52) tedavide periapikal ve interradiküler lezyonlarla birlikte patolojik kök rezorbsiyonu görülmüştür. 3 (\%6.52) tedavide ise köklerin tamamen rezorbe olduğu ve geniş bir lezyonun bulunduğu tespit edilmiștir. Ayrıca periapikal veya interradiküler lezyon görülmeyen 2 (\%4.37) tedavide ise fizyolojik kök rezorbsiyonunu andıran, kök rezorbsiyonu sonucu kemik içerisinde kalan gutaperkalara rastlanmıștır. Sisteme kayıtlı hasta bilgilerine göre 1 (\%2.17) dişte apse-fistül formasyonu ile birlikte ekstraoral şişlik, 2 (\%4.37) diște mobilite, 7 (\%15.2) diște ağrı şikayeti tespit edilmiştir.

Yapılan değerlendirmeler sonucunda; başarısız olarak değerlendirilen dişlerde görülen lezyonların küçük apikal lezyondan; yaygın, dişi içine alan lezyonlara kadar değişkenlik gösterdiği tespit edilmiştir. Lezyonlara hızlı ilerleyen patolojik kök rezorbsiyonunun eşlik ettiği ve başarısız tedavilerin çoğunluğunda apikal ve furkal lezyonların birlikte seyrettiği görülmüştür.

\section{TARTIŞMA}

$\mathrm{Bu}$ çalışmada pedodonti kliniğinde daimi diş germi eksik olan süt azı dişlerinin daimi kanal tedavisi materyali ile tedavisinin uzun dönem retrospektif tarama ve takibi yapılmıştır. Süt azı dişlerine ait gutaperka/kök kanal dolum patı ile yapılan kanal tedavilerinin sistemde kayıtlı radyografileri ve sistemde kayıttı bilgileri incelenerek başarı durumları değerlendirilmiștir. Buna göre daimi diş germi olmayan süt azı dişlerine uygulanan gutaperka/kök kanal dolum patı ile yapılan tedavilerin başarı oranlarının düşük olduğu tespit edilmiştir.

Tarama sonucu belirlenen 30 (\%35.7) hastanın kayıtlı kontrol radyografilerinin ve klinik bilgilerinin eksik olması çalışmanın limitasyonlarındandır. Bunun yanında çalışmaya dahil edilen hasta sayısının yetersiz olması ve dahil edilen her hastanın bütün zaman dilimlerinde (6 ay, 1 yll, 2 yll, 3 yll) kontrol radyografisinin ve klinik bilgisinin olmaması da çalışmanın eksik taraflarındandır. Fakat, çalışmanın uzun dönem takip içermesi, gutaperka/kök kanal dolum patı ile yapılan tedavilerdeki yüksek başarısızlık oranı gibi bulguları literatüre katkı sağlayacak prospektif klinik çalışmalara ışık tutacaktır.

Araştırma konusu ile ilgili yapılan literatür taramasında gutaperka/kök kanal dolum patı ile kök kanal tedavisi yapılarak takip edilen bir yayına 
rastlanmamıștır. Yapılan çalıșmaya en yakın klinik çalışma Bezgin ve ark. ${ }^{7}$ tarafından MTA grubu ve gutaperka/AH plus grubu olarak 20 dişin 2 gruba randomize edilerek karşılaștımalı olarak yapıldığı yayındır. Bu çalışmada süt azı dişlerinin kanal morfolojisinin daimi dişlerden daha kompleks olması sebebi ile enfekte dokunun çıarılması, kanalların preperasyonu ve dolumunun zor olduğu belirtilmiștir. Tedavinin prognozunu etkileyen en önemli durumların materyalin örtme kabiliyeti ve antibakteriyel etkinliği olduğu belirtilmiștir. MTA materyalinin örtme kabiliyetinin daha üstün olduğu söylenmiştir. Çalışmadan çıkan 3 yıllık takip sonucuna göre MTA ile dolum yapılan grupta $\% 80$ başarı görülürken, gutaperka/AH Plus ile dolum yapilan grupta \%30 bașarı görülmüștür. Çalışmanın gutaperka grubunda elde edilen klinik sonuç bu çalıșmadaki sonuçları destekler niteliktedir.

Literatürde daimi diș germi olmayan süt azı dișleri ile ilgili daha çok vaka sunumları mevcuttur. Moretti ve ark. ${ }^{3} 7$ yaşında bir çocuğun derin dentin çürüklü ve daimi diş germi olmayan 85 numaralı dişinin tedavisini MTA materyali ile amputasyon tedavisi uygulayarak gerçekleştirmişlerdir. 2 yll boyunca takip edilmiş ve klinik ve radyografik olarak başarılı olduğu ve dişin vitalitesini koruduğu belirtilmiştir. Tunç ve Bayrak ${ }^{8}$ daimi diș germi olmayan 8 yașındaki çocuğun devital 85 numaralı dișini MTA materyali ile pulpektomi tedavisi uygulayarak takip etmişlerdir. 36 ay sonunda yapılan muayenede radyografide mezial kökte rezorbsiyon gözlenmesine rağmen klinik olarak semptomsuz olduğu, infraokluzyon ya da ankiloz belirtisi

göstermediği belirtilmiştir. O-Sulliwan ve Hartwell 1220 yaşında bir hastanın daimi diş germi olmayan 75 numaralı dişine MTA ile kanal tedavisi yaparak 4 ay süre ile takip etmișler ve başarılı olduğunu söylemişlerdir. Tebbed ve ark. ${ }^{13}$ yaptıkları çalışmada, 14 yașındaki hastanın fistül ve apsesi mevcut 85 numaralı dișine daimi diş germi mevcut olmadığı için MTA ile dolum yapmışlardır. Takipler süresince iyileşmenin devam ettiğini ve 3 yllın sonunda apikal radyolüsensinin büyük oranda iyileștiğini ve mezial kök ucunda rezorbsiyon görülmesine rağmen dişin arktaki yerini başarılı şekilde koruduğunu bildirmişlerdir.

Literatür incelendiğinde, MTA ile yapılan vakaların yanında bir de guta perka/kök kanal dolum patı ile yapılmış vaka raporu görülmüștür. Kaur ve ark. ${ }^{14}$ daimi diş germi eksik 9 yaşındaki hastanın 75 numaralı dișini preperasyonu takiben gutaperka ve çinko oksit öjenol patı ile doldurup 6 ay boyunca takip etmişlerdir. Herhangi bir semptom veya problem ile karşılaşmamışlar ve başarılı kabul etmişlerdir. Jevanandan ${ }^{11}$ yaptığı vaka sunumunda 12 yaşındaki hastanın 55 numaralı dişine Biodentin ile kanal dolumu yapmış ve 24 aylık takibinde periapikal lezyon veya mobiliteye rastlamamıștır.

Bu çalışmada elde edilen bulgulara göre gutaperka/ kök kanal dolum patı ile yapılan kök kanal tedavileri büyük oranda başarısızlıkla sonuçlanmıştır. Klinik olarak semptoma sebep olmadan daha çok radyolojik bulgular gözlenmiștir. En sık karşılaşılan durumlar yaygin periapikal ve interradiküler lezyonlar ile patolojik kök rezorbsiyonlarıdır. Bu durum bize kanalların efektif bir şekilde mikroorganizmalardan arındırılamadığını ve hermetik dolumların yapılamadığını göstermiştir.

Özetlenen vaka sunumlarına ilave olarak Bezgin ve arkadaşlarının yaptığı karşılaştırmalı çalışmaya göre de daimi diș germi eksikliği mevcut süt azı dişlerinin kök kanal tedavilerinde MTA ve Biodentinin alternatif bir dolum materyali olabileceği görülmüştür. $\mathrm{Bu}$ çalışmada gutta perka/kök kanal dolum patı ile yapılan tedavilerin başarısının düşük olduğu göz önüne alındığında; bundan sonraki tedavi süreçlerinde diğer materyaller de değerlendirilmelidir. Daha fazla hasta ile, prospektif olarak yapılan daha geniş çaplı klinik çalışmalara ihtiyaç vardır.

\section{SONUÇ}

Bu çalışmada konjenital daimi diş eksikliğine sahip hastaların süt azı dişlerinin kök kanal tedavileri gutaperka/kök kanal dolum patı ile tamamlandığında, uzun dönem klinik başarılarının düşük olduğu görülmüştür. Çalışma sınırlı hasta sayısı üzerinden değerlendirildiği için dar kapsamlı olduğu görülmektedir. $\mathrm{Bu}$ sebeple alternatif kök kanal dolum materyalleri ile karşılaștımalı, daha fazla hastanın dahil edildiği uzun dönem prospektif çalıșmaların yapılması önerilmektedir.

\section{KAYNAKLAR}

1- Jia L, Zhang X, Shi H, Li T, Lv B, Xie M. The clinical effectiveness of calcium hydroxide in root canal disinfection of primary teeth: a meta-analysis. Med Sci Monit. 2019;25:2908-2916.

2- Sarı S, Okte Z. Success rate of Sealapex in root canal treatment for primary teeth: 3-year follow-up. Oral Surg Oral Med Oral Pathol Oral Radiol Endod. 2008;05:e93- 96.

3- Moretti ABS, Oliveira TM, Sakai VT, Santos CF, Machado MAAM, Abdo RCC. Mineral trioxide aggregate pulpotomy of a primary second molar in a patient with agenesis of the permanent successor. Int Endod J. 2007;40:738-745.

4- Moskovitz M, Sammara E, Holan G. Success rate of root canal treatment in primary molar. J Dent. 2005;33:41-47.

5- Chen X, Liu X, Zhong J. Clinical and radiographic evaluation of pulpectomy in primary teeth: a 18-months clinical randomized controlled trial. Head Face Med. 
$2017 ; 13: 12$.

6- Arikan V, Sonmez H, Sari S. Comparison of two base materials regarding their effect on root canal treatment success in primary molars with furcation lesions. Biomed Res Int. 2016;2016:1-7.

7- $\quad$ Bezgin T, Ozgul BM, Arikan V, Sari S. Root canal filling in primary molars without successors: Mineral trioxide aggregate versus gutta-percha/AH-Plus. Aust Endod J. 2015;42:73-81.

8- Tunc ES, Bayrak S. Usage of white mineral trioxide aggregate in a non-vital primary molar with no permanent successor. Aust Dent J. 2010;55:92-95.

9- Bjerklin K, Bennett J. The long-term survival of lower second primary molars in subjects with agenesis of the premolars. Eur J Orthod. 2000;22:245-255.

10- Ansari G, Mirkarimi M. Gutta percha root filling in 2nd primary molar teeth with missing successor: a challenging approach. Res J Med Sci. 2008;2:251-254.

11- Jeevanandan G. Obturation of a retained primary maxillary second molar using biodentine ${ }^{\mathrm{M}}$ : a case report. J Clin Diagn Res. 2017;11:ZD34-ZD36.

12- O'Sullivan SM, Hartwell G. Obturation of a retained primary mandibular second molar using mineral trioxide aggregate: a case report. J Endod. 2001;27:703705.

13- Tebbeb N, Zouiten S, Chafra H, Boughzala A. Pulpectomy using mineral trioxide aggregate of a nonvital primary molar with no permanent premolar successor. Endod. 2017;29:164-168.

14- Kaur J, Gupta B, Mahajan N. Management of missing successor of second primary molar teeth with gutta percha as a root canal filling material. Clin Dent. 2018;XI:20- 24 